\title{
消炎䤃素剂の溶出試験と腾溶性皮膜の耐酸性の評価
}

\author{
田部和久, 小林淳子, 澤ノ井政美*1, 山崎 勝, 鎌田 盿*2 \\ 大阪大学微生物病研究所附属病院薬郕部*1 \\ 大阪大学薬学部薬剂学教室 $* 2$
}

\section{Dissolution Test of Anti-inflammatory Enzyme Preparations and Evaluation of Acid Resistance of Their Enteric-coated Films}

\author{
KaZUHisa TANabe, JUNKo Kobayashi, Masayoshi SAWANOI, ${ }^{* 1}$ \\ MASARU YAMAZAKI, and AKIRA KAMADA*2 \\ Hospital Attached to the Research Institute for Microbial Diseases, Osaka University*1 \\ Faculty of Pharmaceutical Sciences, Osaka University*z
}

\author{
(Received February 10, 1984)
}

\begin{abstract}
Pharmaceutical properties of 4 kinds of anti-inflammatory enzyme preparations were discussed. All preparations met JP X disintegration test and weight variation test. Activity of the enzyme dissolved by both rotating basket and paddle methods was compared within 120 min in $\mathrm{pH} 6.0$ test fluid as enteric-coated films begin to dissolve. Activity curves of each product showed similar pattern in both methods. Product $\mathrm{C}$ was not disintegrated completely in pH 6.0 and 8.0 test fluids even after $120 \mathrm{~min}$. To evaluate acid resistance of enteric-coated film of each product, activity of the enzyme dissolving in JP disintegration test fluids was measured. It is suggested that acid resistance of each product is satisfactorily kept in the 1st fluid, because its maximum activity in 2 nd fluid was equal to that in optimal $\mathrm{pH}$ range. Activity curve of the enzyme dissolving in $\mathrm{pH}$ shift test fluid was different from each other, and each maximum activity was nearly equal to that in optimal $\mathrm{pH}$ range. From these results, it is considered that 4 kinds of the preparations tested should have been kept under a quality control for acid resistance of the enteric-coated films. However, as core tablet of the product $C$ was not satisfactorily disintegrated in test fluid studied, improvement on its disintegration property is needed.
\end{abstract}

Keywords — anti-inflammatory enzyme ; dissolution test ; enzyme activity ; acid resistance ; enteric-coated films

\section{はじめに}

中性拉よび弱アルカリ性に至適 $\mathrm{pH}$ を有する酵素は, 酸性域で失活することが多い，そのため製剤化する際に は腸溶性皮膜を施している，腸溶性製剂は皮膜物質やコ 一ティング方法が異なり，一般にはノウハウになってい ろ. Seaprose-S 製剤では, 酵素の放出パターンや皮膜 耐酸性が製品間で差のあることをすでに報告した.1) ま

*1 吹田市山田丘3-1；Yamadaoka 3-1, Suita, 565 Japan

*2 吹田市山田丘1-6 ; Yamadaoka 1-6, Suita, 565 Japan
た腸溶性の消化酵素剤や消炎酵素剂は, 皮膜の耐酸性が 製品の品質を評価するうえで非常に重要な因子であるこ とも報告した。 ${ }^{2,3)}$

最近の薬効再評価により, 前報引)で報告した消炎酵素 剤の複合剂は単一成分の製剤となり，1個中の醭素含量 が増え，活性単位が高められている：また流通段階での 品質保証や治療効果を高める目的から, 製剤面の改良が 施されていると考えられる. 著者らはこれまでの腸溶性 製剤の溶出試験には, 崩壊試験器を用いて検討してき た.JP X から新たに溶出試験法が試験項目飞追加され たので，今回はこの装置を用いて腸溶性消炎酵素片の溶 出試験を行い, 皮膜の耐酸性を評価すると同時に，2種 
類の試験方法について比較を行ったので報告する.

英 験 方 法

\section{1. 料}

Table 1 は今回の実験に使用した 4 種類の製品で，同 一ロット番号のものを用いた．製品 B は腸溶性顆粒を内 容物としたカプセル剤で，その他は腸溶性錠剤である.

実験に供した試薬のうち、フェノール試楽以外はすべて 試薬特級を用いた。

\section{2. 臬量倔差試験}

JP X 重量偏差試験法の錠郕およびカプセル剤の項に 従い，直示天科 (島津製作所, LIBROR L-160 DTP)を 用いて測定した.

\section{3. 崩壊侙騟}

JP X 崩壊試験法の腸溶性の製剂の項に従い，崩壊試 験器（富山産業, T- $2 \mathrm{H}$ 型）を使用した.

\section{4. 䁖来力価の測定}

酵素力価は, Casein-Folin 呈色 B法4)を改变した方法 で測定した. 基質液はカゼイン（acc. to Hammarsten, Merck 社) $600 \mathrm{mg}$ を精秤し，1\% ホウ砂液 $50 \mathrm{ml}$ を 加えて水浴上で 5 分間加熱溶解し, 冷後 $1 \mathrm{~N}$ 塩酸で $\mathrm{pH}$ 8.0 亿調整したのち, pH 8.0塩酸・ホウ砂緩衝液で全量 $100 \mathrm{ml}$ とし, 綿柽ろ過した。

カゼイン基質液 $5 \mathrm{ml}$ をあらかじめ $37^{\circ} \mathrm{C}$ に加温して おき, 試料液 $1 \mathrm{ml}$ を加えて正確に 10 分間反応させたの ち，1.8\%トリクロル酢酸沈殿試薬 $5 \mathrm{ml}$ を速やかに加 えて反応を停止し， $37^{\circ} \mathrm{C}$ で30分間放置後ろ過した。一 方対照液は, 試料液 $1 \mathrm{ml}$ に $1.8 \%$ トリクロル酢酸沈殿 試薬 $5 \mathrm{ml}$ ，カゼイン基質液 $5 \mathrm{ml}$ を加えて混和し， $37^{\circ} \mathrm{C}$ で30分間放固後ろ過した. 各ろ液 $2 \mathrm{ml}$ に $10 \%$ 炭酸ナト リウム液 $5 \mathrm{ml}, 3$ 倍希积フェノール（フォリン・チオカ ルトー) 試楽 $1 \mathrm{ml}$ を加光, $37^{\circ} \mathrm{C}$ で20分間加温して発 色させ，波長 $660 \mathrm{~nm}$ 飞和けるとれぞれの吸光度を測定
した．別にチロジンを用いて検量線を作製し，さきの吸 光度差より生成チロジン量を算出した。

\section{5. 溶出試臨}

酵素の溶出試験は JP X 溶出試験装置（富山産業, TMB-8 型) を用いた. 試験液 $900 \mathrm{ml}$ を $37 \pm 0.5^{\circ} \mathrm{C} に$ 保ち，擤拌速度を $100 \mathrm{rpm}$ とし，回転バスケット法と パドル法で行った。

5-1. 一定 $\mathrm{pH}$ 試験液

$\mathrm{pH} 6.0$ はリン酸緩衝液, $\mathrm{pH} 8.0$ は塩酸・ホウ砂緩衝 液を用いて120分まで測定した.

5-2. JP X 崩壊試験液（第 1 液, 第 2 液)

第 1 液で錠剤は 120 分間, カプセル内の腸液性顆粒は 60分間汼覮したのち速やかに第 2 液に移し, 溶出する醅 素の力価を60分まで測定した.

5-3. 経時的 $\mathrm{pH}$ 变化試験液

本実験では試験液を $900 \mathrm{ml}$ としたので，前報”の試 験液組成および補充液を变更した。すなわち $\mathrm{pH} 2.6$ 初 期試験液 $\left(1 \ell\right.$ 中 $\mathrm{Na}_{2} \mathrm{HPO}_{4} \cdot 12 \mathrm{H}_{2} \mathrm{O} 2 \mathrm{~g}, \mathrm{NaCl} 2.2 \mathrm{~g}$, 希塩酸 $3.3 \mathrm{ml}$ 含有) $900 \mathrm{ml}$ を用い, 試料採取後の補充 液として No. $1 \sim 5$ は・0.1 $\mathrm{MNa}_{2} \mathrm{HPO}_{4} 2 \mathrm{ml}$ を, No. 6 $\sim 11$ は $4 \% \mathrm{Na}_{2} \mathrm{CO}_{3}$ 液 $2 \mathrm{ml}$ をそれぞれ用いた。 な打試 験液の採取時間は前報1)と同じである。

\section{实験轺果および考寮}

\section{1. 重具倔盖侙験}

重量偏差試験結果を Table 2 に示した。 4 品目とも JP X 重量偏差試験飞適合した. 製品 $\mathrm{A}, \mathrm{B}, \mathrm{D}$ は変動倸

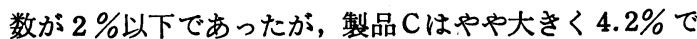
あった.

\section{2. 崩壊試験}

Table 3 には崩壊試験による結果を示した．各製品と す第 1 液では全く崩壊せず, 第 2 液では規定時間内に崩 壞した．腸溶性顆粒の製品 Bは 4〜5 分で完全に崩壊し

Table 1. Anti-inflammatory Enzyme Preparations

\begin{tabular}{|c|c|c|c|}
\hline Product & Formulation & Lot No. & $\begin{array}{l}\text { Component } \\
\text { ( Activity unit ) }\end{array}$ \\
\hline A & Tablet & 0940 & $\begin{array}{l}\text { Serrapeptase } \\
(10000 \text { Serrapeptase unit ) }\end{array}$ \\
\hline B & Capsule & 564 & $\begin{array}{l}\text { Pronase } \\
(9000 \text { Tyrosine unit ) }\end{array}$ \\
\hline C & Tablet & $\mathrm{C} 011$ & $\begin{array}{l}\text { Bromelain } \\
(40000 \text { Bromelain unit ) }\end{array}$ \\
\hline $\mathrm{D}$ & Tablet & CF22A0 & Seaprose-s $15 \mathrm{mg}$ \\
\hline
\end{tabular}


Table 2. Results of Weight Variation Test

\begin{tabular}{|c|c|c|c|c|}
\hline & & & & $=20$ \\
\hline Product & $\begin{array}{r}\text { Mean } \pm \text { S.D. } \\
(\mathrm{mg})\end{array}$ & $\begin{array}{l}\text { Max. } \\
(\mathrm{mg})\end{array}$ & $\begin{array}{l}\text { Min. } \\
\text { (mg) }\end{array}$ & C.v. a) \\
\hline A & $154.3 \pm 2.3$ & $158.5^{\circ}$ & 148.7 & 1.5 \\
\hline B & $183.2 \pm 3.0$ & 189.9 & 178.6 & 1.7 \\
\hline $\mathrm{C}$ & $296.6 \pm 12.5$ & 317.4 & 273.3 & 4.2 \\
\hline $\mathrm{D}$ & $167.5 \pm 3.1$ & 172.8 & 161.3 & 1.8 \\
\hline
\end{tabular}

a) Coefficient of variance

Table 3. Results of Disintegration Test

\begin{tabular}{ccccc}
\hline & & \multicolumn{2}{c}{$\mathrm{n}=6$} \\
\hline Product & $\begin{array}{c}\text { Disintegration time } \\
\begin{array}{c}\text { 1st } \\
\text { luid }\end{array}\end{array}$ & $\begin{array}{c}\text { 2nd } \\
\text { fluid }\end{array}$ & $\begin{array}{c}\text { Max. } \\
\text { (min) }\end{array}$ & $\begin{array}{c}\text { Min. } \\
\text { (min) }\end{array}$ \\
\hline A & 14.2 & 20 & 11 \\
B & - a) & 4.5 & 5 & 4 \\
C & a) & 23.8 & 29 & 21 \\
D & a) & 15.8 & 18 & 12 \\
\hline
\end{tabular}

a) Not disintegrated

たが，製品Cは20分以上を要した。

\section{3. 一定 pH 試験液における溶出試験}

飯沼ら ${ }^{5,6)}$ は腸溶性製剂が小腸上部で速やかに崩壊す る条件を検討し, in vitro の崩壊試験では, $\mathrm{pH} 5.0$ では

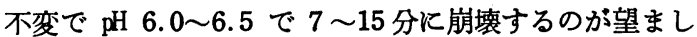
いと報告している．そこで回転バスケット法により $\mathrm{pH}$ 6.0 試験液に溶出する酵素力価を 120 分まで求めたのが Fig. 1 である.

腸溶性顆粒の製品 Bは60分後に最高値を示した．製品 Dは40分から60分後に最も多く溶出した．製品Aは 120 分後にはバスケット内に残存物は認められなかったの で, 120 分後の力価が最高値であるといえる．製品Cは 120 分後もバスケット内には中心錠がほとんど崩壊せず に残っていた．そこで 120 分後に中心錠をガラス棒でつ ぶした時の酵素力価は生成チロジン量が $8 \mathrm{mg}$ であった ので, 120分の時点で酵素は全体量の 1/3〜1/4 しか溶出し ていないことが明らかとなった.

$\mathrm{JP} \mathrm{X}$ 溶出試験には回転バスケット法とパドル法があ るが, 腸溶性製剤の溶出試験については特に記載されて いない. 製品Cのように回転バスケット法では 120 分後
も崩壊しなかったところから, 試験方法により溶出パタ ーンが異なることが考えられる.そこでパドル法により $\mathrm{pH} 6.0$ 試験液に溶出する酵素力価を求めたのが Fig. 2 である。

4 製品とも回転バスケット法による溶出曲線 (Fig. 1) と類似したパターンを示した．製品Cを除く 3 品目は, 最高力価に達する時間がやや早くなる傾向にあった. 製 品 Cは30分ごろから糖衣層部分が半分にわれ，中心錠が 露出してくるのが観察された。 パドル法と回転バスケッ ト法とでは, 顕著な差が認められなかった. パドル法で はカプセル崩壊後は顆粒がシンカーから試験液に分散 し，錠剂と実験条件が異なることになる．これらを考虑 して従来から繁用している回転バスケット法で溶出試験 を行らことにした。

4 製品に処方されている酵素は, 活性至適 $\mathrm{pH}$ 域が 8 付近にあるので, $\mathrm{pH} 8.0$ 試験液に溶出する酵素の力価 を求めたのが Fig. 3 である.

腸溶性顆粒の製品Bは酵素活性が速やかに現われ，20 分後に最高力価を示したが，その後は漸減して 120 分後 には40\%の減少を認めた. 製品Aは60分後に最高値を示 


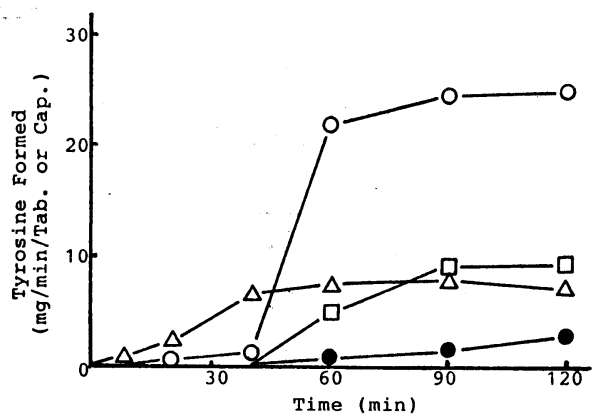

Fig. 1. Activity Curves of the Enzyme Dissolved from Preparations in $\mathrm{pH} 6.0$ Test Fluid Using JP X Rotating Basket Method

$\square$, product $A$; $\triangle$, product $\mathrm{B} ; \mathrm{O}$, product $\mathrm{C}$ $O$, product $\mathrm{D}$.

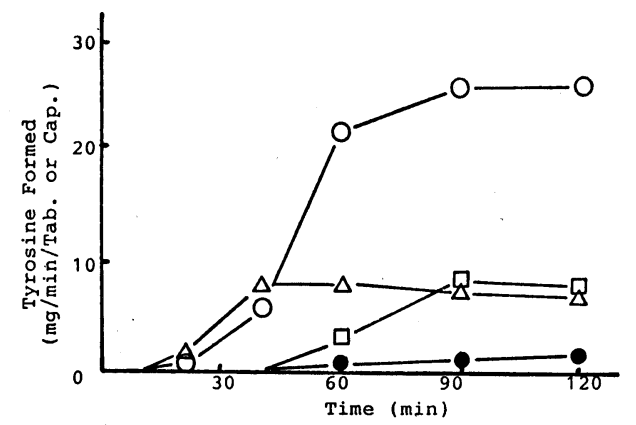

Fig. 2. Activity Curves of the Enzyme Dissolved from Preparations in $\mathrm{pH} 6.0$ Test Fluid Using JP X Paddle Method Key : see Fig. 1.

し，120分までは同じ活性を持続した．製品Dは20分か ら40分で速やかに力価が上昇し，60分後には最高力価と なった．製品Cは40分ごろから徐々に酵素は溶出する が，力価の上昇は遅く，120 分後でもバスケット内に錠 剂の一部が残存していた。 pH 6.0 試験液の場合と同じよ らに，残存の錠剤を崩した時の力価は $8.1 \mathrm{mg}$ であっ た. 製品 C の腸溶性皮膜の溶解後, 力価の上昇がほぼ直 線的であることから, 中心錠の崩壊様式は表面溶解形で あると推察される。

\section{JP X 崩境侙験浓（第 1 液，第 2 液）における恣} H咸负

晹溶性の消炎酵素剂は, 皮膜の耐酸性が製剤の品質を 保持するうえで重要な因子となっている．したがって崩 壊試験たけでなく，その試験液による溶出試験を行い， 第 2 液に溶出する酵素の力価から製昘の安定性を検討す る必要がある. Fig. 4 には, JP X 崩壊試験法の腸溶性

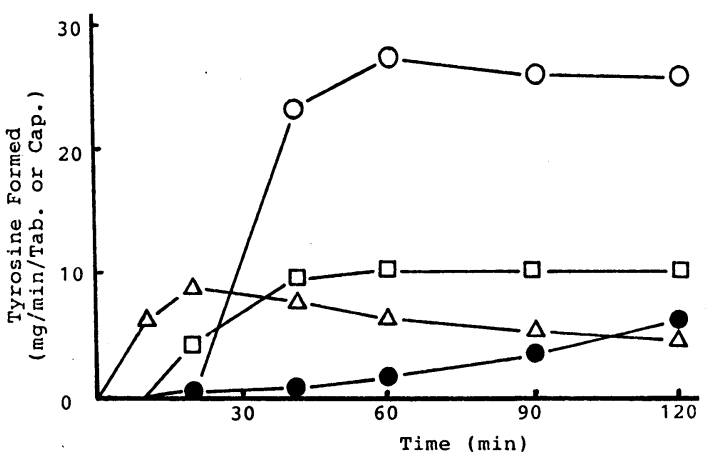

Fig. 3. Activity Curves of the Enzyme Dissolved from Preparations in pH8.0 Test Fluid

Key : see Fig. 1.

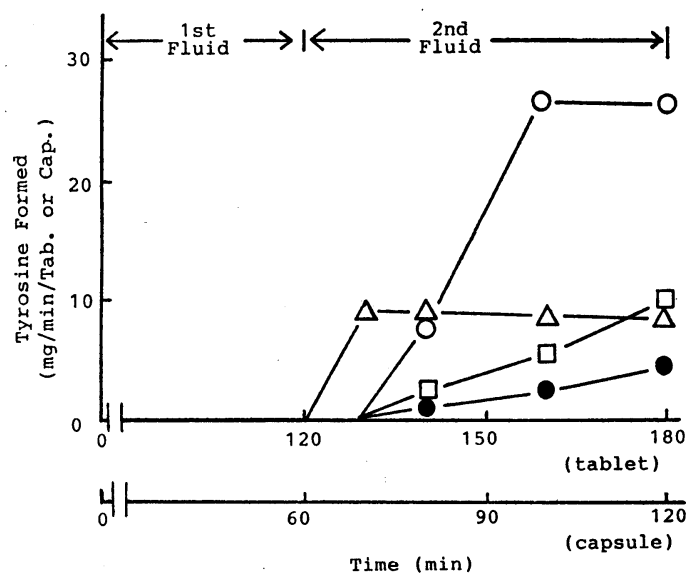

Fig. 4. Activity Curves of the Enzyme Dissolved from Preparations in JP X Disintegration Test Fluids

Key : see Fig. 1.

の製剤の項に従い，第 2 液に溶出した酵素の力価を示し た。

第 2 液で 100\% 溶出するに要した時間は，製品 Bが10 分後, 製品 Dが40分後, 製品 $\mathrm{A}$ が60分後であった。最高 力価は $\mathrm{pH} 8.0$ の力価 (Fig. 3) とほとんど同じであっ たので，第 1 液による酵素の失活はないと考えてよい， 製品 Cは第 2 液の60分後す完全に崩壊しなかったので, ガラス棒で崩したのちの力価は $\mathrm{pH} \mathbf{8 . 0}$ の力価に等しか った．したがって腸溶性皮膜は他の 3 品目と同じように 耐酸性を有していたといえる。

\section{5. 経時的 $\mathrm{pH}$ 变化試榆液}

医薬品の内服による消化管内移行に対し，pH 変化に 伴ら製剤の挙動を把握するのは非常に困難である．著者 


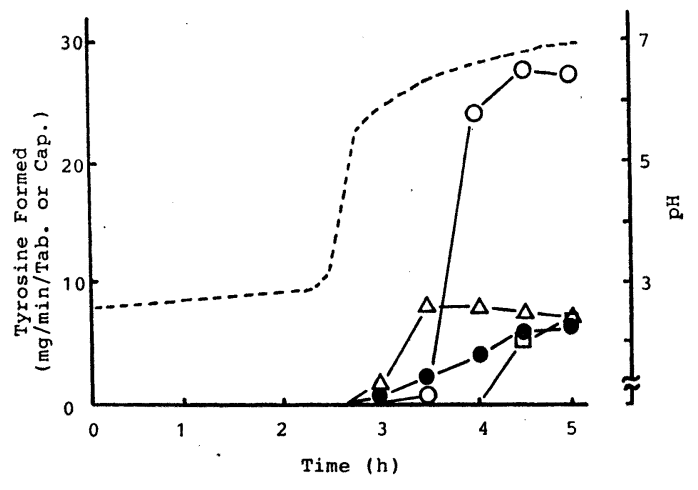

Fig. 5. Activity Curves of the Enzyme Dissolved from Preparations in $\mathrm{pH}$ Shift Test Fluid

Key : see Fig. $1 ;-$, enzyme activity ; ......, $\mathrm{pH}$.

らは消化管の $\mathrm{pH}$ 変化を考慮した試験液を調製し, 総合 消化酵素剂2)や Seaprose-S 製剂1) 飞適用した結果, 薬 物の溶出曲線から製剤の崩壊性, 腸溶性皮膜の耐酸性, および薬物の溶出し始める $\mathrm{pH}$ などを同時に求めること ができた．神代らクや紀氏ら た試験液を調製し，製剤の品質評価を行っている．また 上野ら9)は L-Keflex 顆粒の製剂的評価をするのに経時 的 $\mathrm{pH}$ 変化試験液を用い, 製剤の特徵を把握することが できたと報告している，そこで今回の消炎酵素剂に経時 的 $\mathrm{pH}$ 変化試験液を用い, 溶出する酵素の力価を求めた のが Fig. 5 である.

腸溶性顆粒の製品 Bは $\mathrm{pH}$ が急激に上昇した180分後か ら酵素は速やかに溶出し， 210 分後には最高力価を示し た. 製品Dは $\mathrm{pH} 6$ 以上となる210分後から速やかに力価 の上昇がみられ， 270 分後の最高力価は至適 $\mathrm{pH} 8.0$ の 值に等しかった. 製品 $\mathrm{A}$ ○では 300 分後もバスケット 内に中心錠が一部残存しているのが観察された. そこで さらに摫汼時間を延長し，完全に崩壊し酵素が溶出した
時の力価を測定した．その結果, 酵素力価は至適 $\mathrm{pH} 8.0$ の力価と等しかったので，腸溶性皮膜は十分に耐酸性を 有していることが明らかとなった。

\section{結䜊}

今回実験に供した 4 種類の製品は, JP X 重量偏差試 験および崩壊試験に適合した。また腸溶性製剤として非 常に重要な皮膜の耐酸性に関しても，十分な品質が保た れていることが明らかとなった．製品Cは腸溶性皮膜が 溶解したあとの中心錠の崩壊性は十分であるとはい古 ず，製剤的に改良するのが望ましいと思う．JP X 溶出 試験の回転バスケット法とパドル法で溶出パターンはほ ぼ同じとなったが、他の製剤についても同じ結果が兄ら れるとはいえない，今後多くの腸溶性製剤の溶出試験を 行い，試験方法を確立すべく検討を重ねてゆく予定であ る.

\section{文嘀}

1）田部和久, 益池豊, 大西 昇, 平岡栄一: 病院 薬学, 6, 41 (1980).

2) 田部和久, 門林宗男, 畑田昭雄, 平岡栄一 : 病院 薬学, 6, 21 (1980).

3) 田部和久, 千葉幹夫, 閏林宗男, 畑田昭雄, 平岡 栄一: 病院薬学, 5, 85 (1979).

4) 赤堀四郎編 : “醅素研究法第 2 巻”, 朝倉書店, 東 京, 1956, p. 242 .

5）飯沼龍一, 萬谷有甫, 土田和男, 沢野昭三 : 日病 薬雑誌, 10, 223 (1974).

6）飯沼龍一, 莺谷有甫, 土田和男, 長谷川恵子：日 本薬学会第96年年会搼演要旨集, 1976年 4 月.

7) 神代 昭, 内海紀子, 内藤真佐子 : 九州薬学会会 報, 27,9 (1973)。

8）紀氏沉恵, 西井諭司, 山路 昭, 平岡栄一: 病院 薬学, 3, 150 (1977).

9）上野和行, 福永敬三, 田中義一, 杉本欣司, 平野 善信, 尾崎照美: 病院薬学, 7, 300 (1981). 